IRA-International Journal of Management \& Social Sciences

ISSN 2455-2267; Vol.12, Issue 02 (August 2018)

Pg. no. 41-48.

Institute of Research Advances

http://research-advances.org/index.php/RAJMSS

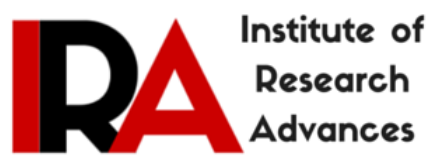

\title{
Motivations that Sustain the Work of Volunteers in Community Based Palliative Care: A Qualitative Exploration
}

\author{
K Krishnakumar ${ }^{1 \#} \&$ R Nalini ${ }^{2}$ \\ ${ }^{1}$ Research Scholar, Department of Social Work, Pondicherry University, Puducherry, India. \\ ${ }^{2}$ Professor \& Head, Department of Social Work, Pondicherry University, Puducherry, India. \\ \#corresponding author. \\ Type of Review: Peer Reviewed. \\ DOl: http://dx.doi.org/10.21013/jmss.v12.n2.p4
}

\section{How to cite this paper:}

Krishnakumar, K., Nalini, R. (2018). Motivations that Sustain the Work of Volunteers in Community Based Palliative Care: A Qualitative Exploration. IRA-International Journal of Management \& Social Sciences (ISSN 2455-2267), 12(2), 41-48. doi:http://dx.doi.org/10.21013/jmss.v12.n2.p4

(C) Institute of Research Advances.

\section{(cc) EY-NC}

This work is licensed under a Creative Commons Attribution-Non Commercial 4.0 International License subject to proper citation to the publication source of the work.

Disclaimer: The scholarly papers as reviewed and published by the Institute of Research Advances (IRA) are the views and opinions of their respective authors and are not the views or opinions of the IRA. The IRA disclaims of any harm or loss caused due to the published content to any party.

Institute of Research Advances is an institutional publisher member of Publishers International Linking Association Inc. (PILA-CrossRef), USA. The institute is an institutional signatory to the Budapest Open Access Initiative. Hungary advocating the open access of scientific and scholarly knowledge. The Institute is a registered content provider under Open Access Initiative Protocol for Metadata Harvesting (OAI$P M H)$.

The journal is indexed \& included in WorldCat Discovery Service (USA), CrossRef Metadata Search (USA), WorldCat (USA), OCLC (USA), Open J-Gate (India), EZB (Germany) Scilit (Switzerland), Airiti (China), Bielefeld Academic Search Engine (BASE) of Bielefeld University, Germany, PKP Index of Simon Fraser University, Canada. 


\begin{abstract}
Countries like India where there is a greater burden on public health care system, due to high population rates, have highest potential to use volunteering as an alternative to increasing human resource demand. Community based palliative care model is one of the successful models of extending health care services which necessarily involves the work of volunteers in a community. This model has been very successful in the Indian state of Kerala. The aim of the study was to identify the factors which actively motivate and sustain the work of volunteers in community based palliative care. Case study research design was employed in this study. The current study identifies altruism, spirituality, personal experiences and better social relationships as the prime motivations of volunteers in community based palliative care. Identification of volunteer motivations would better help in devising sustainable participatory health care programmes.
\end{abstract}

Key Words: Volunteer motivation, Community based, Palliative Care

\title{
INTRODUCTION
}

For the public health approaches to be effectual, they must be owned by the community.(Stjernswärd, Foley, \& Ferris, 2007) It is a sad fact that palliative care services are poorly managed in the developing world. Two third of patients in need of health provisions during terminal illnesses hail from low or middle income countries.(Stjernswärd, 2007)Shortage of resources, coupled with illiteracy and poverty make the development of palliative care services a major challenge.(Shanmugasundaram, Chapman, \& O'Connor, 2006)Palliative care services are best delivered through an interdisciplinary team, involving the work of medical doctors, nursing professionals, social workers, and community volunteers.(Khosla, Patel, \& Sharma, 2012)

The Indian state of Kerala has shown a swift advancement in the area of community based palliative care. (S. K. Kumar, 2007; McDermott, Selman, Wright, \& Clark, 2008). Neighbourhood network in palliative care is a notable model which involves community participation in the delivery of palliative care services as its essential component. Home based care is indeed a priority along with institutional care.(Rajagopal \& Palat, 2002) Homebased palliative care are preferred widely and thus mandates the need for wider practice.(Joseph, Jayarama, \& Kotian, 2009)Recruitment of volunteers is essential for meeting the man power requirements in developing economies. Volunteers have the potential to cover wider area in community education and health care.(Bunn, 2016)The community based palliative care programmes recruit volunteers from the immediate community. Training is imparted to the volunteers who then identify the chronically ill in their vicinity and provide effective intervention with dynamic support from a network of medico-social professionals. (Kumar \& Numpeli, 2005) The volunteers from the community helps in empowering family members of the patients and ensures sustenance of the care delivery system.(Bollini, Venkateswaran, \& Sureshkumar, 2004)

Volunteering in community based palliative care is often motivated or sustained by a variety of factors ranging from personal choices to a commitment towards a greater cause. Certain factors lead and further inspire people to volunteer in palliative care settings. The energy or the 'impetus' that sustains the work of palliative care volunteers in community based palliative care is the subject matter of this social enquiry. This would further aid in recruitment and selection of volunteers and ensure greater volunteer retention rates. (Planalp \& Trost, 2009a) Knowledge of motivation levels of volunteers is essential for ensuring the sustainability of the programme.(Muckaden \& Pandya, 2016)An understanding of these motivating factors would help in improved volunteer training and thereby reflect in the quality of services delivered.

\section{METHOD}

The aim of the study was to identify the factors which actively motivates and sustain the work of volunteers in community based palliative care. Therefore a qualitative approach was adopted as it allows an exploration of plurality of perspectives. Moreover, there is further scope in qualitative approach as it allows exploration of participants' outlooks, opinions and experiences. Case study research design was employed in this study. Qualitative case study methodology is a prized method in public health research to develop theory, programme evaluation and for the development of effective interventions.(Baxter \& Jack, 2008)

\section{Sample and geographical location of the study}

The study was undertaken in the Ernakulam and Thrissur districts of Kerala, India among volunteers working in community based palliative care programmes. The study involved purposive sampling. Potential participants were approached individually and the objects and expectations of this research were explained to them. Subjects were recruited from both public as well as Private NGO/ Charity based programmes. Seven cases were female 
whereas four cases were male. Total 11 cases were selected. The case selection procedure considered emphasis on typical cases. Informed consent was obtained from all the subjects under this study.

\section{Data collection and analysis}

Open ended semi-structured interview schedule was used in this study. Community volunteers were interviewed until data saturation was reached. Each interview lasted for 30-45 minutes. Data saturation was achieved by the $11^{\text {th }}$ interview and thus data collection ceased thereafter. The data acquired from the eleven participants were analysed. Significant words, expressions, and sections were labelled. The responses identified as appropriate, centred around the objectives of the study were coded. These codes were then grouped under major themes. Love towards fellow humans, Spiritual meaning in life and Personal experiences were identified as major themes. Other less common themes were extending social relationships and personal development. The verbatim quotations of best exemplars from the participants are presented at times.

\section{RESULTS}

Here are the extracts of themes that arose following the interviews of 11 volunteers.

\section{Love towards fellow humans}

Love towards fellow humans emerged as a highlighted theme of this study. Almost all the cases who were interviewed in this study stress on the community's responsibility in serving its members during conditions of terminal illnesses, regardless of monetary benefits. In fact, this philosophy itself is the basic idea behind community based palliative care.

"We all are susceptible to various kinds of illnesses. Actually, we don't know what is going to happen in the next minute...... Such conditions can occur for anyone, anytime. It is the responsibility of the members of the community to serve the bedridden patients of their vicinity". (Case 2 Female)

Another case states, "We cannot demand fee for our service, as we are humans who care for fellow humans, which is our moral responsibility". (Case 6 Male)

Comfort of the suffering individuals is considered as of primary importance in community based care. Life at homes is often preferred over prolonged care at hospices. This not only reduces the economic burden of patient's family but also provides the community members an opportunity to care for the patient at his/her comfort.

"I have seen my grandparents dying; they died peacefully by hearing Ram's name and by drinking water of the Ganges. All relatives use to come together at a person's last days. Now the condition is lot different, people die at isolated wards at hospices. People have become more self-centred, and it is high time for one to volunteer. It is to express selfless love towards fellow beings" (Case 10 Male)

One of the cases comments that 'life become worthy when we live for others.' For most of the cases under consideration, work in palliative care is something that adds meaning to their lives. The work at palliative care is also seen as a continuing 'give and take policy'. It is obvious that those who have cared for others have the right to get back from society. As per the opinion of a case under this study, it is the moral obligation of the society to help back the community members who help people in trouble.

\section{Spiritual meaning in life}

Evidences from the field have identified spirituality as a leading factor for people to volunteer at the community based palliative care settings. Six of the subjects have identified volunteering in palliative care as their purpose in life.

"I would say that I started living with full satisfaction, only after being a part of the home care programme. Now my soul is full as I identified my real purpose in life. I would say that I am leading a blessed life"(Case 2 Female)

It is a fact that till date, a universally accepted definition of spirituality has not evolved yet. The respondents of the study identify spirituality both within and beyond theistic definitions. Comprehension of god and its qualities is itself varied among the respondents. Almost every respondent in this study except one had firm belief in god. One of the respondents identify work in palliative care as noble only because of the actual worth 
of its action, that is alleviating or managing the pain of suffering individuals. The respondents of this study also identify spirituality with their personal or religious beliefs. Two of them identify the work in palliative care as a 'highly rewarding activity' that it would help them to get blessings from the almighty which indeed brings wellness in psychological and metaphysical realms.

For instance one of the volunteer stated that:

"care of the bedridden individuals, affected by various serious ailments would help us to gain spiritual wellness and peace in current life, I believe it has far reaching rewards beyond this life....towards my afterlife." (case 9, female)

Four respondents have identified the work in community based palliative care as an opportunity to experience life beyond materialism. A lot of colour and grandeur exists in the life we lead; however a craving to identify something beyond this is always a yearning, at least for a few.

"We took birth on earth, get educated, make a living, get married, and raise children... all these can happen for every human. Most often our race in life is for our daily bread. And it is a fact that, we all will die one day. What we have achieved in our race? Nothing! People have become so self-centred........ Palliative care allows me to give a greater meaning to my life beyond materialistic attributes" (Case 11 Female)

Most of the cases had the view that certain phenomena can be explained only through spiritual principles. There are always materials, beyond human comprehension. Scientific exploration of causation of events in lives of people is still limited. The suffering of people cannot be pre-determined at times. Some of the cases believe that it is a plan of some higher energy for them to be a part of palliative care team. This study identifies yearning for spiritual meaning in life as an important theme which considerably persuades the work of a palliative care volunteer in the community.

\section{Personal experiences}

Personal experiences are also an important theme that emerged during this study. Disease of loved ones or of self is one of the primary factors which prompt the work of a volunteer in community based palliative care setting. Almost all the volunteers who were interviewed in this study had touching stories to tell which had inspired them to volunteer. One of the volunteer states that he had a serious accident during his college days due to which he was bedridden for about two years in his life. He underwent many medical operations, after all he has become alright. His mother died while he was at school, due to which all burden of care taking was left with his father. It was his friends and relatives who helped him to come out of his condition. He says "I had seen people suffering due to many serious conditions. But I never thought it would come to me once..." (Case 7, male) After being recovered from this condition, he started volunteering for community based palliative care services, to care for people suffering from terminal illnesses. The volunteers under this study have identified similar conditions which inspired them to volunteer. The participants of this study also had personal experiences of being assisted by relatives and community members during illness conditions of their close relatives. One of the cases stated that his father was bed ridden before his death, a few years ago. The person in the bed had four siblings and their children and relatives; still there was no one to care for them while he was ill other than the neighbours and other community members. This made a realization in the case under study, that people at close proximity can and has wider scope of extending care during prolonged illnesses. Due to this personal experience, a realization has come in him that, beyond the kinship circle, the community members have more possibilities of extending effective support. Realizations from such personal experiences are identified as one of the major factors which actively encourage people to volunteer. Few have become part of the palliative care team, when their family members had experience of receiving help from already enrolled community volunteers.

\section{Other Themes}

Other themes which emerged during the thematic analysis of case study were extending social relationships and personal development. The palliative care volunteers ascertain that there has been a great improvement in their social relationships since they started volunteering. Though often related to altruistic motivations, this indeed is another theme identified in this study. Personal development and improvement in career functions were found to be important to young volunteers. Personal development is rather a benefit of volunteering than a motivation factor for most of the volunteers. 


\section{DISCUSSION}

As per the view of every case taken in this study, love towards fellow humans itself is the major driving force behind the selfless work of palliative care volunteers. Altruistic motives are the major influencing factor for people to volunteer.(Garbay, Gay, \& Claxton-Oldfield, 2015) Altruism is often identified as unselfish concern for the welfare of others. It is just the opposite of egoism. Gregarious nature of humans always binds them towards the community to which they are a part of. The society exists due to mutual co-operation of human beings. All the cases in this study identify social and altruistic values as of primary importance in community based palliative care. Love towards fellow human beings is better expressed through one's involvement in community activities. Altruistic values are also identified as an important factor for pro-social behaviour.(Kahana, Bhatta, Lovegreen, Kahana, \& Midlarsky, 2013) Working for the people who are suffering with various kinds of diseases is also identified as a societal responsibility.(Muckaden \& Pandya, 2016) Primary responsibility of care for sick individuals falls on the immediate community. A strong association do exist between the happiness, satisfaction, general health, and long life of individuals who are psychologically compassionate.(Post, 2005).

Every volunteer has a different definition of Spirituality. Spirituality is identified as a yearning from within, an inner urge to accomplish the ultimate objective in life. Almost all the subjects under this study have been identified as people possessing a higher state of spiritual existence. Indeed this afflatus is crucial in the continuation of volunteer work.(Owen-Still, 2016) Spiritual basis of volunteering is explored in a variety of studies, especially in the hospice settings. Volunteerism itself is identified as a search for more realized life. Spiritual meaning of life is better explored through volunteerism and working for the community.(Korda, 2016) As explored through this study, many people believe that few phenomena can be explained only through spiritual principles.(Hill, Pargament, \& Hood, 2000) Belief in blessings from a higher power is one of the premier motivating factors for people to volunteer.(Edmund Forst \& Healy, 2016) For many of the volunteers, God's love is explored through sharing love with fellow human beings.(Clough, 2018) Studies have shown positive relationship between religious values and volunteerism. (Krause, 2015) Also, it is noted that spiritually motivated volunteers should embrace spiritual diversity.(Hall, 2016) However, spirituality is not always linked to religion. Individuals define spirituality beyond religion. It is rather a connectedness with other humans and the world to which we are a part of. Spirituality is also an important component for psychological well-being of a person.(Ivtzan, Chan, Gardner, \& Prashar, 2013) People derive satisfaction in life by involving in volunteering programmes.(Claxton-Oldfield \& Claxton-Oldfield, 2012) However studies also establish the fact that satisfaction of hospice volunteers also rely on effective appreciation and support.(Chevrier, Steuer, \& MacKenzie, 1994) However few studies establish that volunteer satisfaction tended to be lower during the initial year of volunteering.(Lavenburg \& Bernt, 2012) A lot of individuals who volunteer identify volunteerism to be an act of noble values. Volunteerism is viewed as an act which transcends material values. Quest for spiritual meaning in life helps the volunteers to sustain in their activity. Moreover, religious beliefs are often coping strategies for sustaining the work of a volunteer.(Brown, 2011)

As identified through this study, personal motivations tend to be an important factor which motivates many of the volunteers to work in palliative care. Personal experiences and struggles often make people understand the need to spend time with the community. (Weatherall, 2011). Palliative care volunteers are often motivated by their own personal experiences with death of near ones.(Caidwell \& Scott, 2016; Planalp \& Trost, 2009b)People also consider volunteering as an opportunity to understand about the lives of patients and to gain lessons for life.(Planalp, Trost, \& Berry, 2011)Emotional resilience and personal hardiness, both of which are products of life experiences, have been identified as crucial dimensions for the volunteer's suitability for engaging in palliative care activities. (Guirguis-Younger \& Grafanaki, 2008) The US hospice volunteers have reported altruistic motives as more influential in their volunteer work whereas German hospice volunteers have rated career expectations as of pivotal importance.(Stelzer \& Lang, 2016). A Study among British hospice volunteers confirm altruistic motives as most influential factor for them to join hospice.(Claxton-Oldfield, ClaxtonOldfield, Paulovic, \& Wasylkiw, 2013) Current study reveals that Indian hospice volunteers are driven by the values of altruism and spirituality. However it is true that the younger volunteers tend to have mixed motivations, encompassing both altruistic and personal advances.(Roessler, Carter, Campbell, \& MacLeod, 2016)

\section{CONCLUSION}

Volunteers are the life nodes of palliative care programmes. Exploring the factors in volunteering could improve the quality of palliative care services.(Larson, 2016; Pesut, Hooper, Lehbauer, \& Dalhuisen, 2014) Identification of volunteer motivations would better help in devising sustainable participatory health care 
programmes.(Cloyes, Rosenkranz, Wold, Berry, \& Supiano, 2014)The current study identifies altruism, spirituality, personal experiences and better social relationships as the prime motivations of volunteers in community based palliative care.

Spiritual care for patients is increasingly found to be important in palliative care settings.(Walker \& Breitsameter, 2017). At this context spiritually motivated volunteers can help the family as well as the patients by extending principles driven spiritual care.(Holyoke \& Stephenson, 2017)However, it should be noted that spiritual motivations and actions should be in timbre with accepted standards of the scientific community. Also it is a known fact that, spirituality differs from person to person which means, the volunteer's spirituality should not conflict with the spiritual aspirations of the client system. Spirituality thus needs to be incorporated as an important component in volunteer training. Also, spiritual training as a subject, needs to be culturally appropriate. (Claxton-Oldfield \& Gosselin, 2010) Cultural competency training for the volunteers in community based palliative care settings have far reaching benefits.(Jovanovic, 2012)The authors understand the limitations of case studies as they are not much effective in making generalizations in a wider population. However, the ideas reflected through case studies are better depictions of people's innate perceptions. There is a need for extensive studies in community based palliative care as this could aid in improving the quality of public health care services in developing countries. Collaborative and supportive supervision are essential for assimilation of community health workers into the established health care systems.(Asweto, Alzain, Andrea, Alexander, \& Wang, 2016) Continued research and training is essential for effectiveness of the services delivered through community volunteers.

\section{ACKNOWLEDGEMENTS}

The authors specially thank all the participants of this study. The authors gratefully acknowledge the services of Rehina Raju and Sr. Rose Mary for their services during field work. Special thanks to Akhila, Ursala, Hilallulla \& Arul, Research Scholars, Department of Social Work, Pondicherry University, for their constant support throughout the research period.

\section{FUNDING}

The first author is receiving Junior Research Fellowship of University Grants Commission, New Delhi for his doctoral research.

\section{References}

[1] Asweto, C. O., Alzain, M. A., Andrea, S., Alexander, R., \& Wang, W. (2016, January 1). Integration of community health workers into health systems in developing countries: Opportunities and challenges [Text]. https://doi.org/info:doi/10.15212/FMCH.2016.0102

[2] Baxter, P., \& Jack, S. (2008). Qualitative Case Study Methodology: Study Design and Implementation for Novice Researchers. The Qualitative Report, 13(4), 544-559.

[3] Bollini, P., Venkateswaran, C., \& Sureshkumar, K. (2004). Palliative Care in Kerala, India: A Model for ResourcePoor Settings. Oncology Research and Treatment, 27(2), 138-142. https://doi.org/10.1159/000076902

[4] Brown, M. V. (2011). How they Cope they Cope: A Qualitative Study of the Coping Skills of Hospice Volunteers _ A Qualitative Study of the Coping Skills of Hospice Volunteers. American Journal of Hospice and Palliative Medicine ${ }^{\circledR}, 28(6)$, 398-402. https://doi.org/10.1177/1049909110393946

[5] Bunn, E. G. (2016). Volunteers as the backbone: The most difficult aspect of direct service, volunteering is not the doing, but the being. American Journal of Hospice Care. https://doi.org/10.1177/104990918400100102

[6] Caidwell, J., \& Scott, J. P. (2016). Effective hospice volunteers: Demographic and personality characteristics: American Journal of Hospice and Palliative Medicine ${ }^{\circledR}$. https://doi.org/10.1177/104990919401100212

[7] Chevrier, F., Steuer, R., \& MacKenzie, J. (1994). Factors affecting satisfaction among community-based hospice volunteer visitors , Factors affecting satisfaction among community-based hospice volunteer visitors. American Journal of Hospice and Palliative Medicine®, 11(4), 30-37. https://doi.org/10.1177/104990919401100411

[8] Claxton-Oldfield, S., \& Claxton-Oldfield, J. (2012). Should I Stay or Should I Go: A Study of Hospice Palliative Care Volunteer Satisfaction and Retention. American Journal of Hospice and Palliative Medicine®, 29(7), 525530. https://doi.org/10.1177/1049909111432622

[9] Claxton-Oldfield, S., Claxton-Oldfield, J., Paulovic, S., \& Wasylkiw, L. (2013). A Study of the Motivations of British Hospice Volunteers. American Journal of Hospice and Palliative Medicine ${ }^{\circledR}$, 30(6), 579-586. https://doi.org/10.1177/1049909112462057 
[10] Claxton-Oldfield, S., \& Gosselin, N. (2010). How Can I Help You? A Study of the Perceived Importance of Different Kinds of Hospice Palliative Care Volunteer Support: American Journal of Hospice and Palliative Medicine ${ }^{\circledR}$. https://doi.org/10.1177/1049909110385540

[11] Clough, W. R. (2018). To be Loved and to Love: Journal of Psychology and Theology. https://doi.org/10.1177/009164710603400103

[12] Cloyes, K. G., Rosenkranz, S. J., Wold, D., Berry, P. H., \& Supiano, K. P. (2014). To be Truly Alive: Motivation Among Prison Inmate Hospice Volunteers and the Transformative Process of End-of-Life Peer Care Service. American Journal of Hospice and Palliative Medicine®, 31(7), 735-748. https://doi.org/10.1177/1049909113506035

[13] Edmund Forst, J., \& Healy, R. M. (2016). Correlations among Religion, Commitment, and Volunteer Participation: Psychological Reports. https://doi.org/10.2466/pr0.1991.69.3f.1224

[14] Garbay, M., Gay, M.-C., \& Claxton-Oldfield, S. (2015). Motivations, Death Anxiety, and Empathy in Hospice Volunteers in France. American Journal of Hospice and Palliative Medicine®, 32(5), 521-527. https://doi.org/10.1177/1049909114536978

[15] Guirguis-Younger, M., \& Grafanaki, S. (2008). Narrative Accounts of Volunteers in Palliative Care Settings: American Journal of Hospice and Palliative Medicine ${ }^{\circledR}$. https://doi.org/10.1177/1049909107310137

[16] Hall, S. E. (2016). Spiritual diversity: A challenge for hospice chaplains: American Journal of Hospice and Palliative Medicine ${ }^{\circledR}$. https://doi.org/10.1177/104990919701400505

[17] Hill, P. C., Pargament, K. I., \& Hood, R. W. (2000). Conceptualizing Religion and Spirituality: Points of Commonality, Points of Departure, 27.

[18] Holyoke, P., \& Stephenson, B. (2017). Organization-level principles and practices to support spiritual care at the end of life: a qualitative study. BMC Palliative Care, 16(1), 24. https://doi.org/10.1186/s12904-017-0197-9

[19] Ivtzan, I., Chan, C. P. L., Gardner, H. E., \& Prashar, K. (2013). Linking Religion and Spirituality with Psychological Well-being: Examining Self-actualisation, Meaning in Life, and Personal Growth Initiative. Journal of Religion and Health, 52(3), 915-929. https://doi.org/10.1007/s10943-011-9540-2

[20] Joseph, N., Jayarama, S., \& Kotian, S. (2009). A comparative study to assess the awareness of palliative care between urban and rural areas of Ernakulum district, Kerala, India. Indian Journal of Palliative Care, 15(2), 122. https://doi.org/10.4103/0973-1075.58457

[21] Jovanovic, M. (2012). Cultural Competency and Diversity Among Hospice Palliative Care Volunteers. American Journal of Hospice and Palliative Medicine ${ }^{\circledR}, 29(3), 165-170$. https://doi.org/10.1177/1049909111410415

[22] Kahana, E., Bhatta, T., Lovegreen, L. D., Kahana, B., \& Midlarsky, E. (2013). Altruism, Helping, and Volunteering: Pathways to Well-Being in Late Life. Journal of Aging and Health, 25(1), 159-187. https://doi.org/10.1177/0898264312469665

[23] Khosla, D., Patel, F. D., \& Sharma, S. C. (2012). Palliative care in India: Current progress and future needs. Indian Journal of Palliative Care, 18(3), 149. https://doi.org/10.4103/0973-1075.105683

[24] Korda, L. J. (2016). The benefits of beneficence: Rewards of hospice volunteering: American Journal of Hospice and Palliative Medicine ${ }^{\circledR}$. https://doi.org/10.1177/104990919501200507

[25] Krause, N. (2015). Assessing the Religious Roots of Volunteer Work in Middle and Late Life. Research on Aging, 37(5), 439-463. https://doi.org/10.1177/0164027514541703

[26] Kumar, S. K. (2007). Kerala, India: A Regional Community-Based Palliative Care Model. Journal of Pain and Symptom Management, 33(5), 623-627. https://doi.org/10.1016/j.jpainsymman.2007.02.005

[27] Kumar, S., \& Numpeli, M. (2005). Neighborhood network in palliative care. Indian Journal of Palliative Care, 11(1), 6. https://doi.org/10.4103/0973-1075.16637

[28] Larson, T. J. (2016). Resuscitating and transforming hospice volunteer services: American Journal of Hospice and Palliative Medicine ${ }^{\circledR}$. https://doi.org/10.1177/104990919701400609

[29] Lavenburg, P., \& Bernt, F. M. (2012). Training and Supporting Hospice Volunteers: A Regional Survey. American Journal of Hospice and Palliative Medicine ${ }^{\circledR}, 29(5), 355-361$. https://doi.org/10.1177/1049909111423527

[30] McDermott, E., Selman, L., Wright, M., \& Clark, D. (2008). Hospice and Palliative Care Development in India: A Multimethod Review of Services and Experiences. Journal of Pain and Symptom Management, 35(6), 583-593. https://doi.org/10.1016/j.jpainsymman.2007.07.012

[31] Muckaden, M. A., \& Pandya, S. S. (2016). Motivation of volunteers to work in palliative care setting: A qualitative study. Indian Journal of Palliative Care, 22(3), 348. https://doi.org/10.4103/0973-1075.185083

[32] Owen-Still, S. (2016). Spiritual caregiving: A philosophy for the volunteer-intensive hospice program. American Journal of Hospice Care. https://doi.org/10.1177/104990918500200208

[33] Pesut, B., Hooper, B., Lehbauer, S., \& Dalhuisen, M. (2014). Promoting Volunteer Capacity in Hospice Palliative Care: A Narrative Review. American Journal of Hospice and Palliative Medicine ${ }^{\circledR}, 31(1), 69-78$. https://doi.org/10.1177/1049909112470485

[34] Planalp, S., \& Trost, M. (2009a). Motivations of Hospice Volunteers Motivations of Hospice Volunteers. American Journal of Hospice and Palliative Medicine®, 26(3), 188-192. https://doi.org/10.1177/1049909108330030

[35] Planalp, S., \& Trost, M. (2009b). Reasons for Starting and Continuing to Volunteer for Hospice: American Journal of Hospice and Palliative Medicine®. https://doi.org/10.1177/1049909109333929 
[36] Planalp, S., Trost, M. R., \& Berry, P. H. (2011). Spiritual Feasts: Meaningful Conversations between Hospice Volunteers and Patients. American Journal of Hospice and Palliative Medicine ${ }^{\circledR,}$ 28(7), $483-486$. https://doi.org/10.1177/1049909111398238

[37] Post, S. G. (2005). Altruism, happiness, and health: it's good to be good. International Journal of Behavioral Medicine, 12(2), 66-77. https://doi.org/10.1207/s15327558ijbm1202_4

[38] Rajagopal, M. R., \& Palat, G. (2002). Kerala, India: Status of Cancer Pain Relief and Palliative Care. Journal of Pain and Symptom Management, 24(2), 191-193. https://doi.org/10.1016/S0885-3924(02)00441-4

[39] Roessler, A., Carter, H., Campbell, L., \& MacLeod, R. (2016). Diversity among hospice volunteers: A challenge for the development of a responsive volunteer program: American Journal of Hospice and Palliative Medicine $\AA$. https://doi.org/10.1177/104990919901600506

[40] Shanmugasundaram, S., Chapman, Y., \& O'Connor, M. (2006). Development of palliative care in India: An overview. International Journal of Nursing Practice, 12(4), 241-246. https://doi.org/10.1111/j.1440172X.2006.00576.x

[41] Stelzer, E.-M., \& Lang, F. R. (2016). Motivations of German Hospice Volunteers: How Do They Compare to Nonhospice Volunteers and US Hospice Volunteers? American Journal of Hospice and Palliative Medicine ${ }^{\circledR}$, 33(2), 154-163. https://doi.org/10.1177/1049909114559067

[42] Stjernswärd, J. (2007). Palliative Care: The Public Health Strategy. Journal of Public Health Policy, 28(1), 42-55. https://doi.org/10.1057/palgrave.jphp.3200115

[43] Stjernswärd, J., Foley, K. M., \& Ferris, F. D. (2007). The Public Health Strategy for Palliative Care. Journal of Pain and Symptom Management, 33(5), 486-493. https://doi.org/10.1016/j.jpainsymman.2007.02.016

[44] Walker, A., \& Breitsameter, C. (2017). The Provision of Spiritual Care in Hospices: A Study in Four Hospices in North Rhine-Westphalia. Journal of Religion and Health, 56(6), 2237-2250. https://doi.org/10.1007/s10943-0170396-y

[45] Weatherall, H. (2011, March 18). Life Experiences Motivate Local Hospice Volunteers. Retrieved July 8, 2018, from https://patch.com/massachusetts/hamilton-wenham/life-experiences-motivate-local-hospice-volunteers 